\title{
Phragmites australis and Schoenoplectus californicus in constructed wetlands: Development and nutrient uptake
}

\author{
D. López, M. Sepúlveda and G. Vidal
}

Engineering and Biotechnology Environmental Group, Environmental Science Faculty \& Center EULA-Chile, University of Concepción. P.O. Box 160-C, Concepción-Chile. *Corresponding author: glvidal@udec.cl)

\begin{abstract}
The goal of this work was to evaluate the development and nutrient uptake by Phragmites australis (Phr) and Schoenoplectus californicus (Sch) in horizontal subsurface flow constructed wetlands (HSSF) designed for wastewater treatment. Four HSSF systems with a surface area of $4.5 \mathrm{~m}^{2}$ were planted with Phr and Sch. Wastewater was fed for 3 years at 1.6 to $4.8 \mathrm{~g} \mathrm{~N} \mathrm{~m}^{-2} \mathrm{~d}^{-1}$ and 0.2 to $0.6 \mathrm{~g} \mathrm{P} \mathrm{m}^{-2} \mathrm{~d}^{-1}$. Nutrients (total nitrogen-TN and total phosphorus-TP), organic matter (chemical oxygen demand-COD) and solids (total suspended solids-TSS) were evaluated.

Nitrogen and phosphorus uptake were $7.52 \mathrm{~g} \mathrm{~N} \mathrm{~m}^{-2}$ and $0.83 \mathrm{~g} \mathrm{P} \mathrm{m}^{-2}$ for HSSF-Sch and $11.39 \mathrm{~g} \mathrm{~N} \mathrm{~m}^{-2}$ and 0.23 $\mathrm{g} \mathrm{P} \mathrm{m}^{-2}$ for HSSF-Phr. Showing a development of biomass of HSSF-Sch and HSSF-Phr were $1782 \mathrm{~g} \mathrm{DW} \mathrm{m}^{-2}$ and $385 \mathrm{~g} \mathrm{DW} \mathrm{m}^{-2}$, respectively. Under these conditions, the removal efficiencies were $55-63 \%$ of COD and 88$92 \%$ of TSS for HSSF-Phr and 46-66\% of COD and $83-91 \%$ of TSS for HSSF-Sch. TN removal was $23-24 \%$ for HSSF-Phr and $18-23 \%$ for HSSF-Sch. At the same time, removal for TP was -1 to $4 \%$ for HSSF-Phr and for HSSF-Sch was 9-13\%.
\end{abstract}

Keywords: Constructed wetland, nutrients, Phragmites australis, Schoenoplectus californicus, wastewater 


\section{Introduction}

The populations of rural areas from Chile are dispersed, and now the country has around two million of people in this situation, where only $15 \%$ of these populations have wastewater collection and treatment systems (Araya et al., 2014). Wastewater is characterized by high organic content (biochemical oxygen demand - $\mathrm{BOD}_{5}$ : 200-470 $\mathrm{mg} \mathrm{L}^{-1}$ and chemical oxygen demand - COD: 200-740 $\mathrm{mg} \mathrm{L}^{-1}$ ), total nitrogen (35$\left.100 \mathrm{mg} \mathrm{TN} \mathrm{L}{ }^{-1}\right)$, ammonium (6-66 mg $\mathrm{NH}_{4}^{+}-\mathrm{N} \mathrm{L}^{-1)}$, total phosphorus $\left(6-30 \mathrm{mg} \mathrm{TP} \mathrm{L}^{-1}\right)$, phosphates $(6-30$ $\left.\mathrm{mg} \mathrm{PO}_{4}^{-3}-\mathrm{P} \mathrm{L}^{-1}\right)$ and total suspended solids -TSS (65$500 \mathrm{mg} \mathrm{TSS} \mathrm{L}^{-1}$ ) (Vera et al., 2013; Araya et al., 2014). Constructed wetland $(\mathrm{CW})$ is a technological alternative for removing organic matter and nutrients from wastewater (Vera et al., 2011; Abou-Elela et al., 2013). These engineering systems have been designed to utilize natural vegetation and soil processes and their associated microbial assemblages to assist in treating wastewater (Vymazal, 2011). Specifically, the $\mathrm{CW}$ with a horizontal subsurface flow (HSSF) removes between 67 to $84 \%$ of organic matter in terms of COD (loads of 7.4 to $76 \mathrm{~g} \mathrm{COD} \mathrm{m}^{-2} \mathrm{~d}^{-1}$ ) (Vymazal and Kröpfelová, 2011), 85-91\% of solids, with loads of 2.8 to $10 \mathrm{~g} \mathrm{TSS} \mathrm{m}^{-2} \mathrm{~d}^{-1}, 30-75 \%$ of total nitrogen, with a load of 2.6 a $10 \mathrm{~g} \mathrm{TN} \mathrm{m}^{-2} \mathrm{~d}^{-1}$, and $15-65 \%$ of total phosphorous, with a load of $0.4 \mathrm{~g} \mathrm{TP} \mathrm{m}^{-2} \mathrm{~d}^{-1}$ (Rai et $a l ., 2015)$. In this sense, an important part of the treatment in CW is attributable to the presence and activity of macrophytes and microorganisms (Brezinova and Vymazal, 2015; Rodríguez and Brisson, 2015). The particularly, research has shown that improvements in plant selection play an important role in nutrient removal from wastewater (Malecki-Brown et al., 2010; Vymazal, 2011). The most commonly used genus of plants are the common reed (Phragmites spp.) and bulrush (Schoenoplectus spp.), due to their tolerance to substantial changes in $\mathrm{pH}(4-10)$, salinity (20-45 $\left.\mathrm{mg} \mathrm{Cl} \mathrm{L}^{-1}\right)$, temperature $\left(10-32^{\circ} \mathrm{C}\right)$ and nutrient assimilation (7300-20075 $\mathrm{g} \mathrm{N} \mathrm{m}^{-2} \cdot \mathrm{d}^{-1}, 1095-5475150 \mathrm{~g}$ $\mathrm{P} \mathrm{m}^{-2} \cdot \mathrm{d}^{-1}$ ) (Wallace and Knight, 2006; Vymazal, 2011; Neubauer et al., 2012).

Specifically, Phragmites australis (Phr) is a cosmopolitan macrophyte species, widely used in $\mathrm{CW}$ in Europe. Březinová and Vymazal (2015) reported that aboveground standing stock of $\mathrm{Phr}$ is in the range of 34 to $74 \mathrm{~g} \mathrm{~N} \mathrm{~m}^{-2}$. Zhao et al. (2013) demonstrated that belowground nutrient storage increased during the growing season, with values of 13.2-36.1 $\mathrm{g} \mathrm{N} \mathrm{m}^{-2}$ and 3.0- $6.7 \mathrm{~g} \mathrm{P} \mathrm{m}^{-2}$. Rodríguez and Brisson (2015) reported standing stock in aboveground biomass of Phragmites growing in natural stands in the range of $0.1-2.9 \mathrm{~g} \mathrm{TN} \mathrm{m}^{-2} \mathrm{~d}^{-1}$ removed to loads of $1.1-2.5 \mathrm{~g} \mathrm{TN}$ $\mathrm{m}^{-2} \mathrm{~d}^{-1}$ and $0.05-0.83 \mathrm{~g} \mathrm{TP} \mathrm{m}^{-2} \mathrm{~d}^{-1}$ removed.

Schoenoplectus californicus (Sch) is found from $\left(37^{\circ} 0^{\prime} 0^{\prime \prime}\right.$ north, $120^{\circ} 0^{\prime} 0^{\prime \prime}$ west) California to $\left(54^{\circ} 0^{\prime} 0^{\prime \prime}\right.$ south, $70^{\circ} 0^{\prime} 0^{\prime \prime}$ west) Tierra del Fuego. Sch is an annual or perennial plant with triangular stems up to $3 \mathrm{~m}$ tall and roots that penetrate down to $70-80 \mathrm{~cm}$ (Vymazal, 2011). The foliar biomass production of Schoenoplectus ranges between 350-2000 g DW m ${ }^{-2}$ (MaleckiBrown et al., 2010; Neubauer et al. 2012). Neubahuer et al. (2012) found that Sch foliar biomass contained $12.15 \mathrm{~g} \mathrm{TN} \mathrm{m}^{-2}$ and $1.06 \mathrm{~g} \mathrm{TP}^{-2}$, while rhizomes contained $0.4 \mathrm{~g} \mathrm{TN} \mathrm{m}^{-2}$ and $0.06 \mathrm{~g} \mathrm{TP} \mathrm{m}^{-2}$. The goal of this work was to evaluate the development and nutrient uptake by Phr and Sch in subsurface flow constructed wetlands designed for wastewater treatment.

\section{Materials and Methods}

\subsection{Study area}

The wetland system is located in Hualqui (36 $59^{\circ} 26.93^{\prime \prime}$ south and 7256'47.23" west), Biobío Region, Chile. The influent entering to the HSSF was wastewater 
from a treatment plant that serves a rural community of 20,000 inhabitants. During the period 2011 to 2014 , the average daily temperatures were $11.3{ }^{\circ} \mathrm{C}$ in fall (March to June), $9.8^{\circ} \mathrm{C}$ in winter (June to September), $14.1^{\circ} \mathrm{C}$ in spring (September to December) and $15{ }^{\circ} \mathrm{C}$ in summer (December to March). There were marked seasonal trends of rainfall, with maximum rainfall in the fall and winter $\left(3.1 \mathrm{~mm} \mathrm{~d}^{-1}\right)$ and minimum rainfall of $0.6 \mathrm{~mm} \mathrm{~d}^{-1}$ in the spring and summer.

\subsection{HSSF constructed wetlands}

The HSSF system consisted of four horizontal subsurface flow wetland units. The wastewater used in the HSSF was extracted after pre-treatment (40 $\mathrm{mm}$ bars), and then turn to a primary treatment, consisting of sand trap-degreaser $(630 \mathrm{~L})$, septic tank $(1200 \mathrm{~L})$ and pumping tank $(630 \mathrm{~L})$. Then, the HSSF was then fed by gravity (López et al., 2015). Each HSSF unit had an area of $4.5 \mathrm{~m}^{2}$, a total volume of $1.28 \mathrm{~m}^{3}$ and a water table of $0.4 \mathrm{~m}$ in depth. The support medium was gravel, with an average height of $0.57 \mathrm{~m}$ (Rojas et al., 2013., Navia et al., 2003). Figure 1a shows the HSSF system: two units were planted with the macrophyte species Phragmites australis and labeled (HSSF-Phr1) and (HSSF-Phr2), respectively; and two units were planted with the species Schoenoplectus californicus macrophyte and labeled (HSSF-Sch1) and (HSSF-Sch2), respectively (López et al., 2015). The operational and climatic parameters for the HSSF units were: hydraulic loading (HL) between 19.8-44.6 $\mathrm{mm} \mathrm{d}^{-1}$, and a hydraulic retention time (HRT) between 3 and 7 days. The evapotranspiration rate $(\mathrm{ET})$ presented maximum variations between winter $\left(1.1 \mathrm{~mm} \mathrm{~d}^{-1}\right)$ and summer $(4.0$ $\left.\mathrm{mm} \mathrm{d}^{-1}\right)$.

\subsection{Sampling strategy}

The system was implemented in July 2011. The HSSF were operated for 1163 days. Samplings were taken in the spring (S), summer (Sm), fall (F) and winter (W) over the entire operational period.

In each HSSF, the following measurements were monitored in situ: a) temperature, b) $\mathrm{pH}$, c) oxidation reduction potential (ORP) and d) dissolved oxygen (DO). The parameters are presented as the average between fall and winter $(\mathrm{F} / \mathrm{W})$ and spring and summer $(\mathrm{S} / \mathrm{Sm})$ for each year. HSSF wastewater influent and effluent samples were characterized physicochemically every season. This analysis determined COD, total suspended solids (TSS), TN and TP. In situ and physicochemical characterizations were done every 15 days (López et al., 2015).

\subsection{Macrophyte sampling}

The sampled plants were evaluated with measurements: height (from the base to the apex) and relative abundance (stem $\mathrm{m}^{-2}$ ), with a PVC quadrant of $1 \mathrm{~m}^{2}$ (Neubauer et al., 2012). In addition, above and belowground biomass were determined and a proximate analysis was made.

All macrophyte analyses were done in spring (November 2012), winter (August 2013) and summer (January 2014). Each HSSF was separated into three zones: Zone A (initial zone); Zone B (middle zone); and Zone $\mathrm{C}$ (output zone). The surface area of each zone was $1.5 \mathrm{~m}^{2}$ (Lopez et al., 2015).

\subsection{Analytical methods}

To characterize the influent and effluent of each HSSF, the samples were filtered through Whatman $0.45 \mu \mathrm{m}$ pore size membrane filters. The physicochemical parameters, COD, TN, TP and TSS, were 
measured according to the protocols described in Standard Methods (APHA, 1998). The in situ parameters, $\mathrm{pH}, \mathrm{ORP}$ and temperature, were measured in each HSSF unit using a portable multiparameter OAKTON (PC650-480485). DO was measured using a portable oximeter (oxi 330i/set Hanna HI 9146-04) (Vera et al., 2014; López et al., 2015).
Aboveground and belowground biomass were obtained by dewatering at $75^{\circ} \mathrm{C}$ for $24 \mathrm{~h}$, until reaching constant weight (Neubauer et al., 2012). Proximate analysis was performed for below and aboveground biomass of Phr and Sch. TN was analyzed by digestion and distillation and TP by calcination and colorimetry (Neubauer et al., 2012).
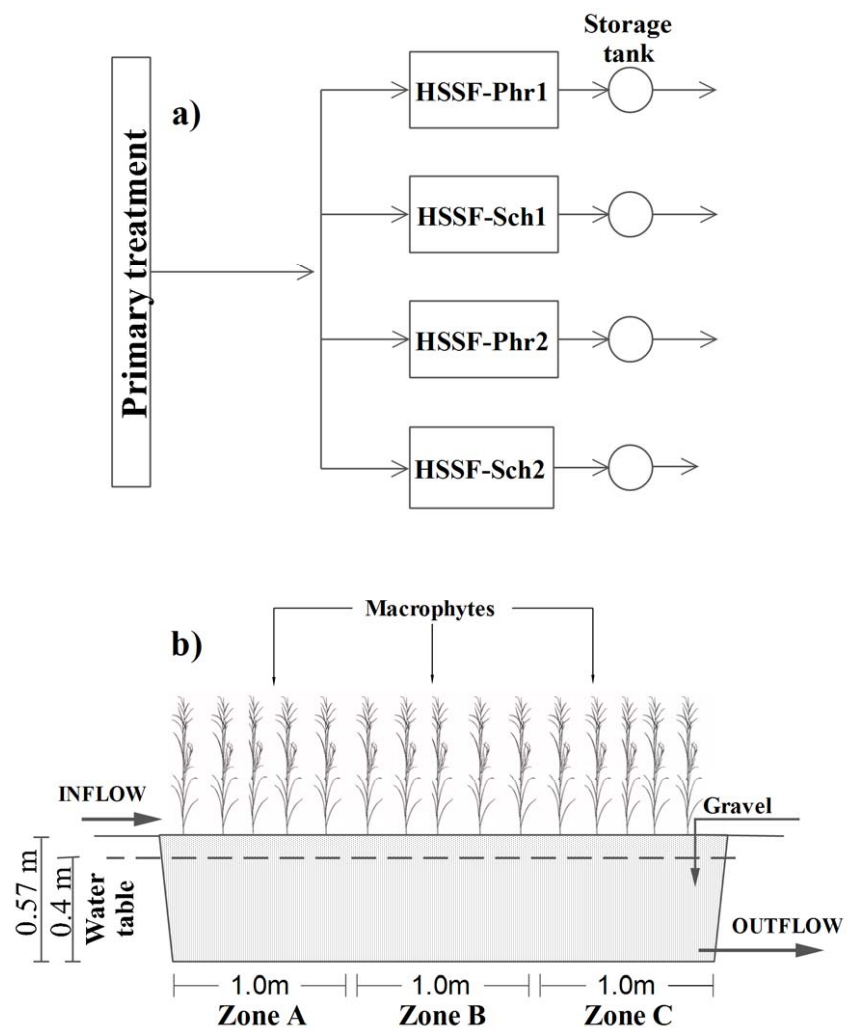

Figure 1. a) Configuring the pilot system of constructed wetlands. HSSF-Phr1 and HSSF-Phr2: units planted with Phragmites australis. HSSF-Sch1 and HSSF-Sch2: units planted with Schoenoplectus californicus; b) Characteristics and sampling points of the HSSF. 


\subsection{Statistical analyses}

Statistical analyses were performed for each HSSF using the statistical program INFOSTAT (Di Rienzo et al., 2011). Previously, data were subjected to a normality test (the Shapiro-Wilk test) to determine the appropriate statistical tests for comparison. To compare the first HSSF to the second HSSF (HSSF-Phr1 vs. HSSF-Phr2; HSSF-Sch1 vs. HSSF-Sch2), (a) data with a normal distribution were analyzed using a paired t-test and (b) data without normal distribution were analyzed with a Wilcoxon test.
To compare the first HSSF and second HSSF between the treatment lines (HSSF-Phr vs. HSSF-Sch), (a) data with a normal distribution were analyzed with a paired t-test and (b) data without normal distribution were analyzed with a Wilcoxon test. Furthermore, to compare the influence of the seasons (spring, Summer, Fall and Winter), (a) data with a normal distribution were analyzed by ANOVA and (b) data without a normal distribution were analyzed by a Kruskal-Wallis test. For all statistical tests, the significance level was $\alpha=0.05$ (López et al, 2015).

Table 1. Physicochemical characterization of the influent

\begin{tabular}{|c|c|c|c|c|c|}
\hline \multirow{2}{*}{ Year } & \multirow{2}{*}{ Seasons } & \multicolumn{4}{|c|}{ Parameter $\left(\mathrm{mg} \mathrm{L}^{-1}\right)$} \\
\hline & & COD & TSS & $\mathrm{TN}$ & $\mathrm{TP}$ \\
\hline \multirow{3}{*}{2011} & Spring & $296 \pm 71$ & $275 \pm 128$ & $93 \pm 11$ & $17 \pm 6$ \\
\hline & & & & & \\
\hline & Summer & $210 \pm 66$ & $342 \pm 194$ & $89 \pm 1$ & $14 \pm 2$ \\
\hline \multirow{3}{*}{2012} & Fall & $260 \pm 38$ & $457 \pm 77^{*}$ & $92 \pm 24$ & $15 \pm 1$ \\
\hline & & & & & \\
\hline & Winter & $420 \pm 72 *$ & $425 \pm 154$ & $88 \pm 65$ & $14 \pm 3$ \\
\hline \multirow{5}{*}{2013} & Fall & $194 \pm 78$ & $147 \pm 115$ & $68 \pm 4^{*}$ & $13 \pm 1$ \\
\hline & Winter & $172 \pm 32 *$ & $137 \pm 44^{*}$ & $120 \pm 16$ & $14 \pm 2$ \\
\hline & & & & & \\
\hline & Spring & $318 \pm 112$ & $256 \pm 44$ & $107 \pm 18$ & $15 \pm 3$ \\
\hline & Summer & $289 \pm 9$ & $124 \pm 33$ & $91 \pm 15$ & $13 \pm 2$ \\
\hline
\end{tabular}

$\mathrm{n}=42$ for $\mathrm{COD} ; \mathrm{n}=38$ for TSS; $\mathrm{n}=31$ for TN and TP. * Significant differences between seasons $(p \leq 0.05)$. 


\section{Results}

\subsection{Characterization of the influent}

Table 1 shows the results of the physicochemical characterization of wastewater influent for 1163 days. During the monitoring period, the influent concentrations variations of COD were $17 \mathrm{mg} \mathrm{L}^{-1}$ (less than $10 \%$ ) higher in the warm seasons $(\mathrm{S} / \mathrm{Sm})$ than in the cold seasons (F/W). Significant differences for COD during winter 2012 and 2013 compared to the others seasons are observed. On the other hand, TSS concentrations presented a maximum increase of $228 \mathrm{mg}$ $\mathrm{L}^{-1}$ in the cold seasons (fall and winter in 2012). TSS significant differences during fall (2012) and winter (2013) with respect to the others seasons are observed. The nutrients contained in the influent varied less than $10 \mathrm{mg} \mathrm{L}^{-1}$, between 1 to $9 \mathrm{mg} \mathrm{L}^{-1}$ for TN and between 0.5-2 $\mathrm{mg} \mathrm{L}^{-1}$ for TP. NT significant differences are observed during Fall 2013 and other seasons ( $p \leq 0.05$ ). No significant differences between seasons were observed for TP $(p \geq 0.05)$.

\subsection{In situ parameters}

Table 2 shows the in situ parameters measured for HSSF-Phr and HSSF-Sch. The pH levels did not change significantly between $\mathrm{F} / \mathrm{W}$ and $\mathrm{S} / \mathrm{Sm}$, with variations between 6.8 and 7.1 for both species ( $p \geq 0.05$ ). Temperatures during $\mathrm{S} / \mathrm{Sm}$ were on average $20.3{ }^{\circ} \mathrm{C}$, with a maximum of $25.4^{\circ} \mathrm{C}$. During F/W, the average temperature was $12.05^{\circ} \mathrm{C}$, with a minimum of $6.4^{\circ} \mathrm{C}$. The oxidation reduction potential for HSSFSch was on average $-258 \mathrm{mV}$ and $-256 \mathrm{mV}$ for HSSF$\mathrm{Phr}$ in both periods. DO was less than $0.46 \mathrm{mg} \mathrm{L}^{-1}$ for both species throughout the monitored period. No significant differences between species of macrophytes for In situ parameters were observed ( $p \geq 0.05)$.

Table 2. Seasonal in situ parameters in the HSSF. $\mathrm{n}=42$ for $\mathrm{pH}$, temperature $\left({ }^{\circ} \mathrm{C}\right), \mathrm{ORP}(\mathrm{mV})$ and $\mathrm{DO}(\mathrm{mg} / \mathrm{L})$.

\begin{tabular}{|c|c|c|c|c|c|c|}
\hline & \multirow[b]{2}{*}{ Year } & \multirow[b]{2}{*}{ Period } & \multicolumn{4}{|c|}{ Parameter } \\
\hline & & & $\mathrm{pH}$ & $\begin{array}{c}\mathrm{T} \\
\left({ }^{\circ} \mathrm{C}\right) \\
\end{array}$ & $\begin{array}{c}\text { ORP } \\
(\mathrm{mV})\end{array}$ & $\begin{array}{c}\mathrm{DO} \\
\left(\mathrm{mg} \mathrm{L}^{-1}\right)\end{array}$ \\
\hline \multirow{4}{*}{$\begin{array}{l}\text { Phragmites } \\
\text { australis }\end{array}$} & 2011 & Spring/Summer & $7.0 \pm 0.0$ & $21.0 \pm 0.2$ & $-233.9 \pm 5.0$ & $0.45 \pm 0.0$ \\
\hline & 2012 & Fall/Winter & $6.8 \pm 0.1$ & $12.8 \pm 0.1$ & $-246.5 \pm 8.3$ & $0.68 \pm 0.1$ \\
\hline & \multirow{2}{*}{2013} & Fall/Winter & $7.0 \pm 0.0$ & $11.6 \pm 0.0$ & $-272.3 \pm 4.1$ & $0.23 \pm 0.0$ \\
\hline & & Spring/Summer & $6.9 \pm 0.0$ & $19.6 \pm 0.2$ & $-271.4 \pm 1.8$ & $0.37 \pm 0.1$ \\
\hline \multirow{4}{*}{$\begin{array}{l}\text { Schoenoplectus } \\
\text { californicus }\end{array}$} & 2011 & Spring/Summer & $7.1 \pm 0.0$ & $21.6 \pm 0.1$ & $-242.8 \pm 4.3$ & $0.44 \pm 0.0$ \\
\hline & 2012 & Fall/Winter & $6.9 \pm 0.0$ & $12.4 \pm 0.3$ & $\begin{array}{c}-228.8 \pm \\
10.1\end{array}$ & $0.67 \pm 0.1$ \\
\hline & \multirow{2}{*}{2013} & Fall/Winter & $6.9 \pm 0.0$ & $11.4 \pm 0.1$ & $-287.3 \pm 2.3$ & $0.21 \pm 0.0$ \\
\hline & & Spring/Summer & $6.9 \pm 0.0$ & $19.0 \pm 0.1$ & $-273.6 \pm 4.1$ & $0.48 \pm 0.1$ \\
\hline
\end{tabular}



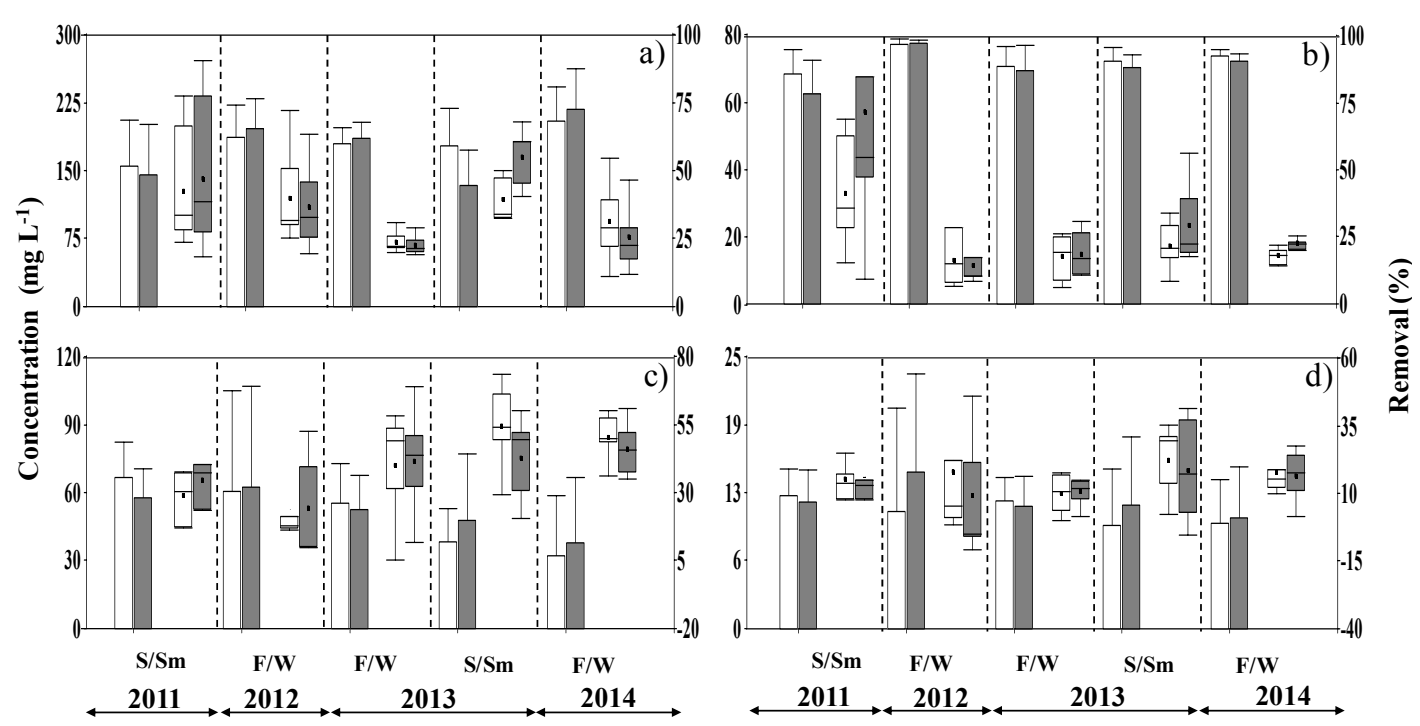

Figure 2. Effluent concentration (box plot) and mean removal efficiency (bar chart) for HSSF-Phr ( $\square$ ) and HSSFSch (匹). (a) COD; (b) TSS; (c) TN; (d) TP.

\subsection{Effluent concentrations and removal efficiencies}

Figure 2 shows the average effluent concentrations (box-plot) and removal efficiency for of COD, TSS, TN and TP (bar chart) by HSSF-Phr (white) and HSSF-Sch (gray) during the monitored seasons. Average COD removal by HSSF-Phr was 55 and 63\% for $\mathrm{S} / \mathrm{Sm}$ and $\mathrm{F} / \mathrm{W}$, with effluent outlet concentrations of 122 and $110 \mathrm{mg} \mathrm{L}^{-1}$, respectively. HSSF-Sch eliminated 46 and $66 \%$ in $\mathrm{S} / \mathrm{Sm}$ and $\mathrm{F} / \mathrm{W}$, with effluent concentrations of 110 and $84 \mathrm{mg} \mathrm{L}^{-1}$. Removal increased from the first to the third year by $17 \%$ and $24 \%$ for HSSF-Phr and HSSF-Sch, respectively. No significant differences between species were observed ( $p \geq 0.05$ ). Removal of solids presented less variation (10\%) between species and seasons, with removal efficiencies of 88 and $92 \%$ for HSSF-Phr and 83 and $91 \%$ for HSSF-Sch in $\mathrm{S} / \mathrm{Sm}$ and $\mathrm{F} / \mathrm{W}$, respectively.
The average outlet concentrations were $20 \mathrm{mg} \mathrm{TSS} \mathrm{L}^{-1}$ for HSSF-Phr and $28 \mathrm{mg} \mathrm{TSS} \mathrm{L}^{-1}$ for HSSF-Sch. No significant differences between species and seasons were observed ( $p \geq 0.05$ ).

TN removal decreases varied seasonally by 15 to $28 \%$. There were minor variations between species and seasons of less than $10 \%$, with an average of 23 and $24 \%$ removal in $\mathrm{F} / \mathrm{W}$ and $\mathrm{S} / \mathrm{Sm}$ for HSSF-Phr, respectively, and 23 and $18 \%$ in F/W and S/Sm for HSSF-Sch, respectively. The same tendency occurred with TP, it is noted a removal decreasing over the three years, with $10 \%$ removal for HSSF-Phr and HSSF-Sch in S/ $\mathrm{Sm}$ (first year) falling to $1 \%$ in $\mathrm{F} / \mathrm{W}$ of the third year of operation. Removal for HSSF-Phr was between -1 to $4 \%$ and for HSSF-Sch was $9-13 \%$ with concentrations of effluent for both species of 12 to $14 \mathrm{mg} \mathrm{L}^{-1}$. No significant differences between species or seasons were observed for NT and PT ( $p \geq 0.05$. 

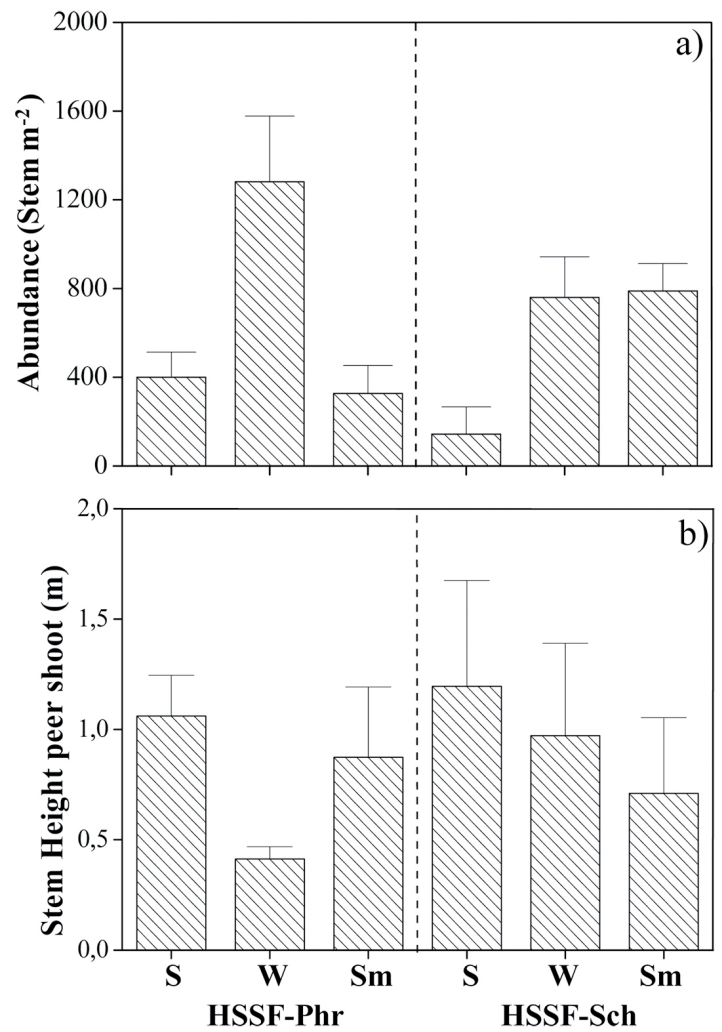

Figure 3. a) Seasonal abundance for Phragmites australis (HSSF-Phr) and Schoenoplectus californicus (HSSFSch). b) Seasonal stem height per shoot. a) Phragmites australis; b) Schoenoplectus californicus

\subsection{Macrophyte development and nitrogen uptake}

Figure 3 shows the plant abundance and height for HSSF-Phr and HSSF-Sch. Figure 3 a shows the number of individuals and/or stems for HSSF-Phr (400 \pm 112 stems), which was significantly $64 \%$ higher than HSSF-Sch ( $143 \pm 122$ stems) during spring $(p \leq 0.05)$. For the first year (winter 2012), the number of stems increased $68 \%$ and $81 \%$ for HSSF-Phr and HSSFSch, respectively. In turn, in the summer the number of individual plants in HSSF-Phr decreased by $75 \%$ due to the effect of a pest (Family: Aphididae).
However, plants in HSSF-Sch were not affected by the pest and maintained their abundance, increasing the number of stems by $3.6 \%$ and reaching coverage of $85 \%$. Stem height varied seasonally by 18 to $61 \%$ for both species. On the other hand, stem size in HSSF-Phr decreased significantly ( $p \leq 0.05$ ) by $61 \%$, from $1.06 \mathrm{~m}$ (spring-466 d) to $0.41 \mathrm{~m}$ during the period of senescence (winter-780 d), but increased size $(0.87 \mathrm{~m})$ during summer (986 d). Stem size in HSSF-Sch decreased by $40 \%$ over time. 

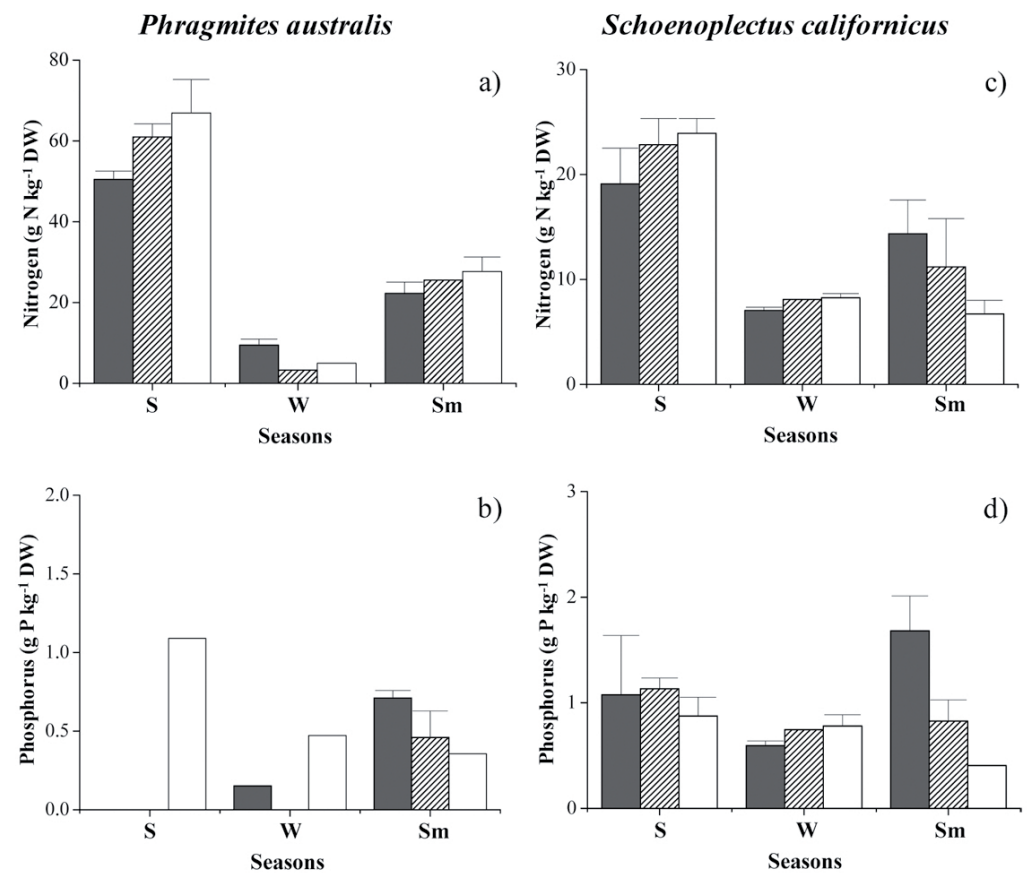

Figure 4. Nitrogen and phosphorus content in plant tissue. (a) and (b) units planted with Phragmites australis; (c) and (d) units planted with Schoenoplectus californicus. Zone A ( $\mathbf{c})$; Zone B ( 8 ) and Zone C ( $\square$ ).

Figure 4 shows seasonal nitrogen and phosphorus content for HSSF-Phr and HSSF-Sch. Nitrogen content for both species was between $57-90 \%$ for HSSF-Phr and 50-64\% for HSSF-Sch, being higher in spring than in the other seasons, significant values $(p \leq 0.05)$. In spring, plant nitrogen content increased along the wetland a $20 \%$ for HSSF-Sch and $24 \%$ for HSSF-Phr. Nitrogen content in spring was 50 and $19 \mathrm{~g} \mathrm{~N} \mathrm{~kg}^{-1} \mathrm{DW}$ in the intake zone (Zone A) of the wetland and 66 and $23 \mathrm{~g} \mathrm{~N} \mathrm{~kg}^{-1} \mathrm{DW}$ in the output zone (Zone C) for HSSF-Phr and HSSF-Sch, respectively. No significant differences between macrophytes $(p \geq 0.05)$, but they were significant between zone $\mathrm{A}$ and zone $\mathrm{C}$ of the wetland $(p \leq 0.05)$. Plant nitrogen content was significantly lowest in winter ( 6 to $8 \mathrm{~g} \mathrm{~N} \mathrm{~kg}^{-1} \mathrm{DW}$ ), with variations of $25 \%$ for HSSF-Phr and HSSF-Sch $(p \leq 0.05)$. In summer nitrogen content in $\mathrm{Phr}$ increased significantly by $19 \mathrm{~g} \mathrm{~N} \mathrm{~kg}^{-1} \mathrm{DW}(p \leq 0.05)$, while it increased by only $2.6 \mathrm{~g} \mathrm{~N} \mathrm{~kg}^{-1} \mathrm{DW}$ in Sch. On average during the three monitored seasons plant phosphorus content was significantly $(p \leq 0.05)$ higher $(40 \%)$ for HSSF-Sch, with $0.86 \mathrm{~g} \mathrm{P} \mathrm{kg}^{-1} \mathrm{DW}$, than for HSSFPhr, with $0.51 \mathrm{~g} \mathrm{P} \mathrm{kg}^{-1} \mathrm{DW}$. P content was more stable for HSSF-Sch (maximum variation of 33\%) over the three seasons, while P content for HSSFPhr varied by up to $72 \%$, significantly different values $(p \leq 0.05)$. In summer phosphorus content was significantly $(p \leq 0.05)$ higher $(57-75 \%)$ in the Zone A ( 0.7 to $\left.1.6 \mathrm{~g} \mathrm{P} \mathrm{kg}^{-1} \mathrm{DW}\right)$ than Zone $\mathrm{C}(0.3$ and $0.4 \mathrm{~g} \mathrm{P} \mathrm{kg}^{-1} \mathrm{DW}$ ) for HSSF-Phr and HSSF-Sch, respectively. 
Table 3. Biomass production and foliar nitrogen and phosphorous content in HSSF-Phr and HSSF-Sch.

\begin{tabular}{|c|c|c|c|c|c|c|c|}
\hline \multirow{3}{*}{ Parameter } & \multirow{3}{*}{ Unit } & \multicolumn{6}{|c|}{ Seasons } \\
\hline & & \multicolumn{2}{|c|}{ Spring } & \multicolumn{2}{|c|}{ Winter } & \multicolumn{2}{|c|}{ Summer } \\
\hline & & HSSF-Phr & HSSF-Sch & HSSF-Phr & HSSF-Sch & HSSF-Phr & HSSF-Sch \\
\hline Biomass Production & $\mathrm{g} \mathrm{DW} \mathrm{m}^{-2}$ & $654 \pm 48$ & $444 \pm 40$ & $1405 \pm 281$ & $1392 \pm 220$ & $385 \pm 145$ & $1782 \pm 177$ \\
\hline \multirow{2}{*}{ Content plant tissue } & $\mathrm{g} \mathrm{N} \mathrm{m}^{-2}$ & $11.39 \pm 0.63$ & $3.25 \pm 0.57$ & $1.28 \pm 0$ & $1.24 \pm 0.06$ & $1.73 \pm 0.5$ & $7.52 \pm 0.76$ \\
\hline & $\mathrm{gP} \mathrm{m}^{-2}$ & $0.23 \pm 0.00$ & $0.45 \pm 0.02$ & $0.08 \pm 0.00$ & $0.12 \pm 0.00$ & $0.19 \pm 0.02$ & $0.83 \pm 0.03$ \\
\hline
\end{tabular}

HSSF biomass production and nutrient content for each species is presented in Table 3. Stem propagation was $32 \%$ higher for HSSF-Phr $\left(654 \mathrm{~g} \mathrm{DW} \mathrm{m}^{-2}\right)$ than for HSSF-Sch (444 $\mathrm{g} \mathrm{DW} \mathrm{m}^{-2}$ ) in spring (466 d), while stem propagation in winter $(780 \mathrm{~d})$ presented only minor variations of $1 \%$ (13 stems). However, in summer (986 d) the number of stems in HSSF-Phr decreased significantly $(p \leq 0.05)$ by $73 \%$ due to pest problems, while the number of plants in HSSF-Sch increased in the same period by $21 \%\left(1782 \mathrm{~g} \mathrm{DW} \mathrm{m}^{-2}\right)$

Table 3 shows the nutrient content in the HSSF species. The maximum seasonal variations in nitrogen content were $10 \mathrm{~g} \mathrm{~N} \mathrm{~m}^{-2}$ for $\mathrm{Phr}$ and $6.28 \mathrm{~g} \mathrm{~N} \mathrm{~m}^{-2}$ for Sch (Statistically significant values with $p \leq 0.05$ ). Major differences (73\%) were observed between species in spring and summer (Statistically significant differences with $p \leq 0.05$ ), while there was little variation in nitrogen content (3\%) for either species in winter $\left(0.04 \mathrm{~g} \mathrm{~N} \mathrm{~m}^{-2}\right)$. Significant differences between seasons and macrophyte species are observed in the content of NT ( $p \leq 0.05)$.

On average the phosphorus content for HSSF-Sch was $0.46 \mathrm{~g} \mathrm{P} \mathrm{m}^{-2}$, which was $65 \%$ higher than that of HSSF$\mathrm{Phr}\left(0.16 \mathrm{~g} \mathrm{P} \mathrm{m}^{-2}\right)$. In turn, the phosphorus content was higher in spring $\left(0.22 \mathrm{~g} \mathrm{P} \mathrm{m}^{-2}\right.$ for $\mathrm{Phr}$ and $0.64 \mathrm{~g} \mathrm{P} \mathrm{m}^{-2}$ for Sch) and summer $\left(0.19 \mathrm{~g} \mathrm{P} \mathrm{m}^{-2}\right.$ for Phr and $0.83 \mathrm{~g}$ $\mathrm{P} \mathrm{m}^{-2}$ for Sch) than in winter $\left(0.08 \mathrm{~g} \mathrm{P} \mathrm{m}^{-2}\right.$ for $\mathrm{Phr}$ and
$0.12 \mathrm{~g} \mathrm{P} \mathrm{m}^{-2}$ for Sch). Significant differences between seasons and macrophyte species are observed in the content of PT $(p \leq 0.05)$.

\section{Discussion}

The average concentrations of the physicochemical influent used in this study were $270 \mathrm{mg} \mathrm{COD} \mathrm{L}^{-1}, 94$ $\mathrm{mg} \mathrm{TN} \mathrm{L}{ }^{-1}$ and $14 \mathrm{mg} \mathrm{TP} \mathrm{L}^{-1}$, which are in agreement with those determined by Henze et al. (2002) who propose a classification for wastewater, determining that the wastewater used in this study correspond to concentrated. The influent solids (270 $\mathrm{mg} \mathrm{TSS} \mathrm{L}^{-1}$ ) were $50 \%$ higher than those found by García et al. (2004), due to the rural origin of the influent, presenting increased solid entrainment.

In situ measurement in the HSSF found no differences in $\mathrm{pH}$ values (6.8-7.1) between species or seasons. These values are consistent with the findings of Vymazal and Kröpfelová, (2011), and García et al. (2004), who worked with wastewater with $\mathrm{pH}$ levels ranging from 6.5 to 7.7. Temperature in the HSSF was directly conditioned by seasonal characteristics associated with a Mediterranean area, with maximum seasonal variations of $10{ }^{\circ} \mathrm{C}$. Furthermore, considering ORP ranges ( -233 to $-287 \mathrm{mV}$ ) and $\mathrm{DO}$ concentration (less than the $0.7 \mathrm{mg} \mathrm{L}^{-1}$ ), an anaerobic condition was 
determined for the HSSF. This agrees with the findings of García et al. (2004) and Vyzamal (2011), who determined values between -351 to $-390 \mathrm{mV}$ and less than $0.1 \mathrm{mg} \mathrm{DO} \mathrm{L}^{-1}$ for HSSF.

Removal efficiencies by HSSF for COD, TSS, TN and TP did not show seasonal differences in Fall/Winter $\left(12.05{ }^{\circ} \mathrm{C}\right)$ and Spring/Summer $\left(20.3^{\circ} \mathrm{C}\right)$. However, there were differences over time during the HSSF operation, which concurs with what Vymazal (2011) found in analyzing HSSFs several countries (Sweden, Norway, the USA and the Czech Republic). Vymazal determined that bacterial activity is not changed with low temperatures. Rather, supplies of carbon and nutrients are the main factors affecting HSSF efficiency. This is why COD removal efficiency improves over time, with a maximum removal of $72 \%(\mathrm{~F} / \mathrm{W}$ in the third year.). However, this is lower than what was found by Vymazal and Kröpfelová (2011), who obtained removal efficiencies of 80 to $94 \%$.

Nitrogen removal was $30 \%\left(0.98 \mathrm{~g} \mathrm{~N} \mathrm{~m}^{-2} \mathrm{~d}^{-1}\right.$ removed $)$ in the first year and less efficient (12\%) by the spring of the third year $\left(0.7 \mathrm{~g} \mathrm{~N} \mathrm{~m}^{-2} \mathrm{~d}^{-1}\right.$ removed $)$. Chen et al. (2014) determined that the efficiency of $\mathrm{CW}$ decreased from 1.05 to $1.10 \mathrm{~g} \mathrm{~N} \mathrm{~m}^{-2} \mathrm{~d}^{-1}$ in the initial stage to 0.23 to $0.31 \mathrm{~g} \mathrm{~N} \mathrm{~m}^{-2} \mathrm{~d}^{-1}$ in the final stage. This could be explained by the fact that $\mathrm{TN}$ loading increased from 2.6 to $3.1 \mathrm{~g} \mathrm{~N} \mathrm{~m}^{-2} \mathrm{~d}^{-1}$. Vymazal (2007) found that at removal efficiencies of $42 \% \mathrm{TN}$ loading was $1.7 \mathrm{~g} \mathrm{~N} \mathrm{~m}^{-2} \mathrm{~d}^{-1}$. Therefore, the low removal rates in the HSSF could be due to limited ammonium nitrification, which in turn is due to lack of dissolved oxygen under permanent saturation (Vymazal and Kröpfelová, 2011).

The efficiency of $\mathrm{P}$ removal by HSSF decreased steadily over the first three years, which concurred with Vohla et al. (2005), who found a decrease from 74.5 to $24.7 \mathrm{~g} \mathrm{P} \mathrm{m}^{-2} \mathrm{yr}^{-1}$, which could be caused by washing Fe content out of the substrate. Mander et al. (2003) observed a decrease of $20.7 \mathrm{~kg} \mathrm{P} \mathrm{yr}^{-1}$ to 5.1 $\mathrm{kg} \mathrm{P} \mathrm{yr}^{-1}$ in an HSSF, which was attributed to the less efficient saturation of the support material. In other research, Vera et al. (2014) determined that the use of gravel as a support medium contributed to $20-50 \%$ of HSSF P removal.

Biomass in HSSF-Phr developed more rapidly during spring, with 400 stems and biomass production of 654 $\mathrm{g} \mathrm{DW} \mathrm{m}^{-2}$ (over $75 \%$ coverage), than HSSF-Sch, which presented less coverage at 50\% (143 and $444 \mathrm{~g} \mathrm{DW}$ $\mathrm{m}^{-2}$ ). This can be explained according to determined by Wallace and Knight, (2006) who indicated that Phr has a propagation rate of $10 \mathrm{~m} \mathrm{yr}^{-1}$ while Sch has one of $15-30 \mathrm{~cm} \mathrm{yr}^{-1}$. The propagation rate of Phr is classified as very rapid and invasive (Wallace and Knight, 2006). Tanner (1996) found a density of $758 \mathrm{stems}^{-2}$ in only 90 days from the start of cultivation. Along the same line, biomass production in HSSF was 23\% higher than that found by Vymazal and Köpfelová (2005) and Zheng et al. (2016) in a CW with Phr production between 500-600 g DW m² (first year). Subsequently, stem production in winter (1281 stems $\left.\mathrm{m}^{-2}\right)$ matched that determined by Rodríguez and Brisson (2015) and Vymazal and Köpfelová (2005), who observed the de-

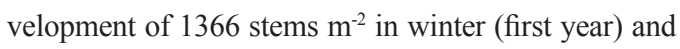
biomass production between 1000 and $1600 \mathrm{~g} \mathrm{DW} \mathrm{m}^{-2}$. Stem and biomass production for Sch during spring (143 stems and $444 \mathrm{~g} \mathrm{DW} \mathrm{m}^{-2}$ ) and winter (760 stems and $1392 \mathrm{~g} \mathrm{DW} \mathrm{m}^{-2}$ ) coincided with Neubauer et al. (2012), who found that Schoenoplectus californicus increased biomass from $522 \mathrm{~g} \mathrm{~m}^{-2}$ in 2009 to $729 \mathrm{~g} \mathrm{~m}^{-2}$ in 2010. In the summer 2013 HSSF-Phr was affected by aphids (family Aphididae), resulting in decreases of $75 \%$ in the number of stems (325 stems) and $72 \%$ in biomass (385 $\mathrm{g} \mathrm{DW} \mathrm{m}^{-2}$ ) in the HSSF-Phr. Meanwhile, the HSSF-Sch was not affected by the aphid attack and biomass increased 21\% (1782 $\left.\mathrm{g} \mathrm{DW} \mathrm{m}^{-2}\right)$. This is because aphids prefer species like Phragmites spp., since Phragmites is a secondary host of aphid in late spring and early summer, almost without exception plant that 
supports high aphid populations (Medina et al., 1986; Tscharntke, 1992; Mook and Wiegers, 1999). There is also evidence that reeds growing at wet sites are more heavily infested than at dry sites. When Phragmites is colonized, the aphids feed on the nutrients in the phloem that extract from the leaves of Phragmites. This result in a decrease of the growth, the leaves are rolled and if the attack is severe can dry the plant, generating a reduction in the production of final biomass (Mook and Wiegers, 1999). Furthermore, photosynthesis is reduced, due to physical effects (fallen leaf) and biological (fungi) generated by excretions of sugars by aphids. Moreover, aphids can transmit toxic substances and/or phytopathogenic virus to Phragmites (Medina et al., 1986). Also, aphids impact on the nutritional chemistry of plants, related negatively to the $\mathrm{P}$ content in leaves and roots (Larsen et al., 2015). Because of this, it is very important to consider the susceptibility to diseases when evaluating the selection of macrophytes in constructed wetlands. Despite the above, improved biomass production is expected in this study. Specifically, because it has been determined that maximum biomass development for Phr is between the third and fourth growing season. Therefore, we expect improved biomass development and consequently improved HSSF efficiency (Vymazal and Köpfelová, 2005).

Nitrogen content for Phr varied between the growing season (spring) and senescence (winter) from 11.39 to $1.28 \mathrm{~g} \mathrm{~N} \mathrm{~m}^{-2}$. This coincides with Tanner (2001), who found $\mathrm{N}$ accumulations in fall of 26 to $47 \mathrm{~g} \mathrm{~N}$ $\mathrm{m}^{-2}$ and in summer (3rd growing season), of $69 \mathrm{~g} \mathrm{~N}$ $\mathrm{m}^{-2}$. Moreover, it has been found that from 0.1 to 0.25 $\mathrm{g} \mathrm{N} \mathrm{m}^{-2} \mathrm{~d}^{-1}$ is released from living plant tissue during senescence. In particular, average $\mathrm{N}$ content (4.8 $\mathrm{g} \mathrm{N} \mathrm{m}^{-2}$ ) for HSSF-Phr was less than $86 \%$ according to Brezinová and Vymazal (2015) and Zhang et al. (2016), who determined an $\mathrm{N}$ content between 30$34.8 \mathrm{~g} \mathrm{~N} \mathrm{~m}^{-2}$ (mean concentration in stems and leaves) for Phr, while, $\mathrm{N}$ content in Sch (1.24 to $7.52 \mathrm{~g} \mathrm{~N} \mathrm{~m}^{-2}$ ) was similar to what was determined by Weller et al. (2015) and Malecki-Brown et al. (2010), who found $\mathrm{N}$ content for Schoenoplectus spp., S. californicus and S. americanus was $5.3 \mathrm{~g} \mathrm{~N} \mathrm{~m}^{-2}, 0.7-2.7 \mathrm{~g} \mathrm{~N} \mathrm{~m}^{-2}$, and $2.9 \mathrm{~g} \mathrm{~N} \mathrm{~m}^{-2}$, respectively.

In turn, the $\mathrm{P}$ content accumulated in the plants in this study ( 0.08 to $0.19 \mathrm{~g} \mathrm{P} \mathrm{m}^{-2}$ ) was less than determined by Zheng et al. (2016), who found accumulations between 1.5-3.0 $\mathrm{g} \mathrm{P} \mathrm{m}^{-2}$.

The variability in $\mathrm{N}$ and $\mathrm{P}$ accumulation between the macrophyte species used in this study reflects the different ways some plant species respond to nutrient-favorable conditions (concentrated wastewater). Some species have greater apparent use efficiency, increasing growth to maximize production, while others tend toward a more conservative strategy of accumulating nutrients, as is the case with Phragmites australis (Tanner 1996). Chen et al. (2014) determined that plant $\mathrm{N}$ consumption increases over time, being 0.9 to 1.7 times greater in the final stages of monitoring, due to root development and plant maturity. This coincides with the results obtained with Sch in our study, which with time increased biomass cover by about $85 \%$, as well as increasing the amount of nutrients in tissues.

On average HSSF-Sch had more (40\%) phosphorus in tissues with $0.86 \mathrm{~g} \mathrm{P} \mathrm{kg}^{-1} \mathrm{DW}$ and $0.51 \mathrm{~g} \mathrm{P} \mathrm{kg}^{-1}$ DW than did HSSF-Phr over the three monitored seasons. In turn, $\mathrm{P}$ content was higher $\left(0.42 \mathrm{~g} \mathrm{P} \mathrm{m}^{-2}\right)$ in spring and summer than in winter $\left(0.1 \mathrm{~g} \mathrm{P} \mathrm{m}^{-2}\right)$. It has been reported that the $\mathrm{P}$ accumulation is in the range of 0.2 to $10.5 \mathrm{~g} \mathrm{P} \mathrm{m}^{-2}$ in various types of $\mathrm{CW}$ and for HSSF it is 0.7 to $5.5 \mathrm{~g} \mathrm{P} \mathrm{m}^{-2}$ (Vymazal and Kröpfelová, 2011). Malecki-Brown et al. (2010) determined that Schoenoplectus californicus has a close to addition $2.5 \mathrm{~g} \mathrm{P} \mathrm{kg}^{-1} \mathrm{DW}$ and $0.55 \mathrm{~g} \mathrm{P} \mathrm{m}^{-2}$. Nitrogen assimilation by $\mathrm{Phr}$ and $\mathrm{Sch}$ were 2 to $12 \%$ and 2 to $28 \%$, respectively. Less than $6 \%$ of the $\mathrm{N}$ 
load that entered the HSSF was assimilated by either plant species. In an investigation of 41 wetland plants, McJannet et al. (1995) found that $\mathrm{N}$ concentrations in plant tissues ranged from 0.25 to $2.14 \%$ and $\mathrm{P}$ concentrations from 0.13 to $1.07 \%$ (Stottmeister et al., 2003). This is corroborated by Vymazal and Kröpfelová (2011), who found that $\mathrm{P}$ and $\mathrm{N}$ levels incorporated by Phragmites australis in HSSF were $2.3 \%$ and $3.7 \%$, respectively. Vohla et al. (2005) determined that the P uptake by plants was $6.1 \%$ and microorganisms to $4.4 \%$ of total removal. P assimilation in this study was less than 5\% for Phr and between 4 and 9\% for Sch. Coinciding, as determined by Vymazal and Kröpfelová (2011); Vohla et al. (2005) and Zheng et al. (2016), who delivered values assimilation by macrophytes in HSSF $2.3-6.1 \% \mathrm{P}$ and $3.7-6.2 \%$ of $\mathrm{N}$ coming into the $\mathrm{CW}$.

In short, a low incidence of plants in removing $\mathrm{N}$ and $\mathrm{P}$ (less than 6\%) contained in the wastewater is evident. However, the role that plants in constructed wetlands has been defined beyond assimilation of nutrients. Thus, it has been determined that constructed wetlands influence directly on regulation of temperature, microbial biomass development, contribute organic matter, aeration rhizosphere, transport of gases, water flow regulation, release of root exudates, esthetic contribution, among others (Chen et al., 2014; Button et al., 2015; Carballeira et al., 2016).

On the other hand, it has been determined that the temporal variability of nutrients and development of biomass accumulate mainly in shoot tissues in spring-summer, but are transferred to belowsoil storage organs during senescence. Indeed, it has been suggested that the removal efficiency in HSSFs can be maximized by make crop before fall to prevent translocation due to senescence.

\section{Conclusions}

There were no differences in removal efficiencies by HSSF for COD, TSS, TN and TP between the F/W $\left(12.05{ }^{\circ} \mathrm{C}\right)$ and $\mathrm{S} / \mathrm{Sm}$ periods $\left(20.3{ }^{\circ} \mathrm{C}\right)$. However, there were differences over time.

By the end of the three-year study, biomass (1782 $\mathrm{g} \mathrm{DW} \mathrm{m}^{-2}$ ) and coverage (85\%) of HSSF-Sch were higher than those of HSSF-Phr $\left(385 \mathrm{~g} \mathrm{DW} \mathrm{m}^{-2}\right.$ and $64 \%$ ). However, the low level of development of HSSF-Phr at the end of the monitoring period was mainly due to an attack by aphids.

The nutrient content in tissues of Sch and Phr presented markedly seasonal trends, with the highest concentrations of nitrogen (7.52 for Sch and $11.39 \mathrm{~g}$ $\mathrm{N} \mathrm{m}^{-2}$ for Phr) and phosphorus ( 0.23 for Phr and 0.83 $\mathrm{g} \mathrm{P} \mathrm{m}^{-2}$ for Sch) during the growing seasons (spring and summer). Therefore, $\mathrm{Phr}$ and Sch are capable of removing a maximum of $6 \%$ of the $\mathrm{N}$ and $\mathrm{P}$ loads applied to the HSSF.

\section{Acknowledgements}

This work was partially supported by Grant No 21110449 from CONICYT (Chile) and CORFO INNOVA BioBio (Chile) under Grant No. 13.3327IN.IIP. The authors also thank the Doctoral Network REDOC.CTA, MINEDUC Grant UCO1202 at the University of Concepcion and CONICYT/ FONDAP/15130015.

\section{References}

American Public Health Association (APHA) 1998. Standard methods for the examination of water and wastewater, 20th ed., Washington D.C.

Araya, F., Vera, L., Morales, G., López, D., Vidal, G. 2014. Las aguas servidas en zonas rurales. En: Las aguas servidas y su depuración en zonas rurales. Ediciones Universidad de Concepción, pp: 9-17. 
Březinová, T., Vymazal, J. 2015. Nitrogen standing stock in Phragmites australis growing in constructed wetlands-Do we evaluate it correctly? Ecol. Eng. 74, 286-289.

Button, M., Nivala, J., Weber, K., Aubron, T., Müller, R. 2015. Microbial community metabolic function in subsurface flow constructed wetlands of different designs. Ecol. Eng. 80, 162-171.

Carballeira, T., Ruiz, I., Soto, M. 2016. Effect of plants and surface loading rate on the treatment efficiency of shallow subsurface constructed wetlands. Ecol. Eng. 90, 203-214.

Chen, Y., Wen, Y., Zhou, Q., Vymazal, J. 2014. Effects of plant biomass on nitrogen transformation in subsurface-batch constructed wetlands: A stable isotope and mass balance assessment. Water Res. 63, 158-167.

Di Rienzo, J., Casanoves, F., Balzarini, M., González, L., Tableda, M., Robledo, C., 2011. InfoStat statistical software. InfoStat Group, FCA, National University of Córdoba, Argentina. 336 pp.

García, J., Aguirre, P., Mujeriego, R., Huang, Y., Ortiz, L., Bayona, J. 2004. Initial contaminant removal performance factors in horizontal flow reed beds used for treating urban wastewater. Water Res. 38, 1669-1678.

Henze, M., Harremoes, P., Jansen, J., Arvin, E. 2002. Wastewater treatment; Biological and chemical processes. In: Enviromental Engineering. Springer-Verlag, Heidelberg, 430pp.

Larsen, J., Jaramillo, P., Nájera, M., González-Esquivel, C. 2015. Biotic interactions in the rhizosphere in relation to plant and soil nutrient dynamics. J. Soil Sci. Plant Nutr.15, 449-463.

López, D., Fuenzalida, D., Vera, I., Rojas, K., Vidal, G. 2015. Relationship between the removal of organic matter and the production of methane in subsurface flow constructed wetlands designed for wastewater treatment. Ecol. Eng. 83, 296-304.
Malecki-Brown, L., White, J., Brix, H. 2010. Alum application to improve water quality in a municipal wastewater treatment wetland: Effects on macrophyte growth and nutrient uptake. Chemosphere, 79, 186-192.

Mander, U., Teiter, S., Kuusemets, V., Lõhmus, K., Öövel, M., Nurk, K., Augustin, J. 2003. Nitrogen and phosphorus budgets in a subsurface flow wastewater treatment wetland. In: Water Resource Management II. Edited by: C.A. Brebbia, Wessex Institute of Technology, UK. 524 p.

McJannet, C., Keddy, P., Pick, F. 1995. Nitrogen and phosphorus tissue concentrations in 41 wetland plants: a comparison across habitats and functional groups. Funct. Ecol. 231-238.

Medina, V., Garrido, A., Jordá, C. 1986. Barley Yellow Dwarf Virus (BYDV) y los áfidos en los arrozales levantinos: una prospección. Bol. San. Veg. $12,135-141$.

Mook, J., Wiegers, J. 1999. Distribution of the aphid Hyalopterus pruni Geoffr. within and between habitats of Common Reed Phragmites australis (Cav.) Trin. ex Steudel as a result of migration and population growth. Limnol. 29, 64-70.

Navia, R., Levet, L., Mora, M.L. Vidal, G., Diez, M.C. 2003. Allophanic soil adsorption system as a bleached kraft mill aerobic effluent post-treatment. Water Air Soil Poll. 148, 323-333.

Neubauer, M.E. Plaza de los Reyes, C. Pozo, G. Villamar C.A., Vidal, G. 2012. Growth and nutrient uptake by Schoenoplectus californicus (C.A. Méyer) Sójak in a constructed wetland fed with swine slurry. J. Soil Sci. Plant Nutr. 12, 421-430.

Rai, U., Upadhyay, A., Singh, N., Dwivedi, S., Tripathi, R. 2015. Seasonal applicability of horizontal sub-surface flow constructed wetland for trace elements and nutrient removal from urban wastes to conserve Ganga River water quality at Haridwar, India. Ecol. Eng. 81, 115-122. 
Rodríguez, M., Brisson, J. 2015. Pollutant removal efficiency of native versus exotic common reed (Phragmites australis) in North American treatment wetlands. Ecol. Eng. 74, 364-370.

Rojas, K., Vera, I., Vidal, G. 2013. Influence of season and species Phragmites australis and Schoenoplectus californicus on the removal of organic matter and nutrients contained in sewage wastewater during the start up operation of the horizontal subsurface flow constructed wetland. Rev. Fac. Ing. Univ. Antioquia. 69, 289-299

Stottmeister, U., Wießner, A., Kuschk, P., Kappelmeyer, U., Kästner, M., Bederski, O., Moormann, H. 2003. Effects of plants and microorganisms in constructed wetlands for wastewater treatment. Biotechnol. Adv. 22, 93-117.

Tanner, C. 1996. Plants for constructed wetland treatment systems - a comparison of the growth and nutrient uptake of eight emergent species. Ecol. Eng. 7, 59-83.

Tanner, C. 2001. Plants as ecosystem engineers in subsurfaceflow treatment wetlands. Water Sci. Technol. 44, 11-12.

Tscharntke, T. 1999. Insects on common reed (Phragmites australis): community structure and the impact of herbivory on shoot growth. Aquat. Bot. 64, 399-410.

Vera, I., García, J., Sáez, K., Moragas, L., Vidal, G. 2011. Performance evaluation of eight years experience from constructed wetlands systems in Catalonia as alternative treatment for small communities. Ecol. Eng. 37, 364-371.

Vera, I., Sáez, K., Vidal, G. 2013. Performance of 14 full-scale sewage treatment plants: Comparison between four aerobic technologies regarding effluent quality, sludge production and energy consumption. Environ. Technol. 34, 2267-2275.

Vera, I., Araya, F., Andrés, E., Saez, K., Vidal, G. 2014. Enhanced phosphorus removal from sewage in mesocosm-scale constructed wetland using zeolite as medium and artificial aeration. Environ. Technol. 35, 1639-1649.
Vohla, C., Poldvere, E., Noorvee, A., Kuusemets, V., Mander, Ü. 2005. Alternative filter media for phosphorous removal in a horizontal subsurface flow constructed wetland. J. Environ. Sci. Heal. 40, 1251-1264.

Vymazal, J. 2007. Removal of nutrients in various types of constructed wetlands. Sci. Total Environ. 380, 48-65.

Vymazal, J. 2011. Long-term performance of constructed wetlands with horizontal sub-surface flow: Ten case studies from the Czech Republic. Ecol. Eng. 37, 54-63.

Vymazal, J., Kröpfelová, L. 2005. Growth of Phragmites australis and Phalaris arundinacea in constructed wetlands for wastewater treatment in the Czech Republic. Ecol. Eng. 25, 606-621.

Vymazal, J., Kröpfelová, L. 2011. A three-stage experimental constructed wetland for treatment of domestic sewage: first 2 years of operation. Ecol. Eng. 37, 90-98.

Wallace, S., Knight, R. 2006. Small-scale constructed wetland treatment systems: Feasibility, Design Criteria, and O\&M Requirements, Final Report, Project 01-CTS-5, Water Environment Research Foundation, Alexandria, Virginia, USA.

Weller, N., Childers, D., Turnbull, L., Upham, R. 2015. Arid land constructed treatment wetlands I: Macrophyte productivity, community composition, and nitrogen uptake. Ecol. Eng. (in press).

Zheng, Y., Wang, X., Dzakpasu, M., Zhao, Y., Ngo, H. H., Guo, W., Xiong, J. 2016. Effects of interspecific competition on the growth of macrophytes and nutrient removal in constructed wetlands: A comparative assessment of free water surface and horizontal subsurface flow systems. Bioresource Technol. 207, 134-141.

Zhao, Y., Xia, X., Yang, Z. 2013. Growth and nutrient accumulation of Phragmites australis in relation to water level variation and nutrient loadings in a shallow lake. J. Environ. Sci. 25, 16-5. 